\title{
Intracranial Hemangioma
}

National Cancer Institute

\section{Source}

National Cancer Institute. Intracranial Hemangioma. NCI Thesaurus. Code C3633.

A hemangioma arising from the brain and meninges. 